\title{
Strain on India-Pakistan Relations through Indian Media
}

\author{
Dr. Masroor Khanum \\ Assistant Professor \\ Department of Mass Communication \\ FUUAST, Karachi-Pakistan \\ Masroor.khanum@fuuast.edu.pk \\ $\&$ \\ Hafiz. Hammaduddin \\ Ph.D Scholar \\ Department of International Relations \\ FUUAST, Karachi-Pakistan \\ hafizhammaduddin@gmail.com
}

\begin{abstract}
This research scrutinizes the evils and implications of Indian journalistic orientation on the already tensed relationship amongst the two neighbor countries. It aims to research the strain on India-Pakistan relations caused through the Indian media. Employing a qualitative content analysis that is grounded on literature review, news, and selective parts of major issues and certain incidents as case study, the research finds evidence of the manipulation of Indian media in favor of their national propaganda, effectively turning a blind eye towards authenticity, objectivity and balance, which represents the most important prerequisites of covering news and events. This study therefore identifies the potential dangers to the harmony and peace between the two countries, and their alias.
\end{abstract}

KEY WORDS: Information, Media, India, Pakistan, International relations. 


\section{INTRODUCTION}

The Indo-Pak memorable contention is one of the most controversial aspects of their relationship. Unfortunately, the narratives don't give a valid and clear picture by media enterprises, which encourage threatening vibes. With modest investigation, one could witness a lot of lies, bluffs and half-truths with the news reporting seen as fallen prey to stereotyping, wishful thinking and false propaganda on both side of the border. Furthermore, the news media authorities have moved away from the ethical considerations necessary for objective journalism. Most of the journalists have turned a blind eye towards authenticity, objectivity and balance, which represent the most important prerequisites of covering news and events. The stereotypes have been so strongly embedded in the cultures of these two nations that departing from such orthodox perceptions seems nearly impossible. The responsibility of such a disturbing trend rests on the conventional antagonists as the progress and development of the entire region is at stake (see, for example, Lyon, 2008) who, in critical circumstances, are putting professionalism and journalistic objectivity at stake in the name of national security.

Indian media has always been depicting a war-scenario. During the terror episodes, India's Government officials and their media start propaganda against Pakistan without notable investigation, which is badly affecting harmony, peace and brotherhood, and encouraging the stereotypical mindsets of the public in India and deliberately increasing tidal waves of war hysteria against Pakistan. It has become fashion to blame Pakistan, its arm forces and ISI for every mishap. News media always compelled Indian incumbent government to take decisive steps against Pakistan and suggested that, as 9/11 forced U.S. to openly and legitimately respond by waging war against terrorism therefore India should and must respond likewise to tackle Pakistan's subsidized extremism and its filthy intelligence designs. Indian Media also terms Pakistan as an untrustworthy neighbor and a strategic wreck, and also thinks of Pakistan as a nation that spreads terrorism on its peaceful neighbor. This study reviews the existing literature on media of both countries to present qualitative evidence in 
support of the abovementioned pattern of lack of professionalism in favor of national security.

\section{RESEARCH METHODOLOGY}

The research methodology of this study is qualitative content analysis of secondary data on Indian media coverage. This includes sources such as books, journals/periodicals, mainstream publications of news reports, articles and featured content, website and weblog content, newspaper coverage and the like.

Qualitative content analysis has been given fundamental standing in this study because almost of the content concerned is documented in the form of videos and interviews instead of quantitative information such as those found for researching in the area of business and corporate activities where quantitative information is documented on the official level. Moreover, the nature and scope of this study requires identification of the manipulative tactics employed using linguistics, which is inherently unstructured.

\section{Literature review and qualitative content analysis}

Media is the sword arm of democracy and acts as watchdog to protect public interest and create public awareness. Media comprises of a significant part of our lives. Media today, in general, includes more than one perspective to be managed. In India the universe of news media is independent of age and viewpoint just as with respect to nationality and doctrine. Political parties dominate Indians news media, introducing their own channels to promote their own principles. Truly, the media in India has been converted into organs of the politicians for primitive abuse. There are at least two huge barriers to the nature of Indian media. One is about expert laxity, which prompts errors and missteps. The other is a class inclination in the decision of what news to cover and what to overlook. The skew in terms of coverage shows that Indian media have not yet matured and so far continues to be oblivious to much larger, meatier and 
far more important issues of national and international importance (Kumar, 2000).

The code of morals approaching precision of realities, limiting damage to sources and subjects, making plans to act autonomously and unreservedly whatever the conditions and assurance to stay straightforward should be the pole carrier for the regular media. However, Indian news channels reports, and inclusion is tied in with making sensation to pull in maximum attention of spectators, foreordained motivation of owners or editors, or the weight of being the first to convey the breaking news to the clients. Underlining the objectivity in news, Indian media has deluged of channels with anchor-driven content, with value for competitive news, leaving the audience starving for facts and impartial coverage of events. In-publicinterest coverage of News channels in India is always for interest to the media houses.

Globalization and its dynamics also saw a massive increase in the flow of international news and content in the Indian media (see, for example, Thussu, 2006). To the extent worldwide relations inclusion and visits by outside dignitaries in Indian media go, Pakistan, China and the US generally rule. When it comes to covering news about Pakistan, news content takes the form of scripted content that is fully sensationalized, with dramatic effect, also with lots of thrill and hatred words. Indian news channels then show baseless reports of events in the country showing in a negative light without supporting evidence, posting greater abundance of charges, and demanding to eliminate all kinds of relationships between the two nations.

Pakistani and Indian societies exist in a continuous phase of hostility, psychological warfare and war hysteria because of conflict-oriented news media industries. The communal and political problems that had led to the division of the subcontinent are expected to have had an impact on the political and social context of both nations and their relations with the international community. The affirmative endeavors taken by the Indian politicians towards tranquility and mutual cooperation are often inhibiting by the forceful propaganda by the news media in India. These one-sided 


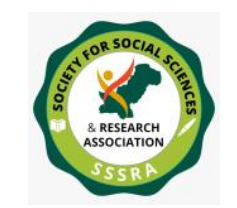

narratives have spawned revulsion and suspicion by humiliating Pakistan and venerating India. Indian Media covers only those stories and events they want the target audience to be familiar with, therefore, the bad events like brutal killings and wars have always been the major focus of news stories. The news media in India have dominantly been entailed in disseminating bitterness, hostility, grudge and above all war propaganda against Pakistan. The intentional objectives of glorifying political interests and demeaning the perceived enemy images were achieved through masscirculation of hostile newspapers, news channels and movies aimed to alter public's beliefs and behaviors and sway their public in order to dominate their respective rival neighbor Pakistan. Indian news media are deeply embedded with political designs and keeping Pakistan politically and socially deprived. Precisely, Indian digital media have filled acres of space between India and Pakistan with coverage on evil events and critical situations without scrutinized facts and figures.

While the media strategies always give the same picture, this media hostility was particularly palpable in its coverage of Mumbai assaults. The sensationalized dramatic progression of Indian news media is contributed much dynamically in 2008 after Mumbai assaults by provoking national patriotism and global attention. The unfortunate inclination of Indian news-media towards conflict-oriented reporting throughout the entire episode of Mumbai assaults ushered both the states to the verge of fierce war that might even had progressed towards nuclear arms. The Indian news media's war inclination journalistic treatment of Mumbai assaults had aggravated the already anxious relational ties amongst the two nations and has made the Indian public even more insensitive and suspicious against Pakistan thereby rendering devastating only due to the media during Mumbai assault. In fact, the harsh memories of Mumbai assaults and its treatment by Indian news media have left profound strains on the relations of both countries (Dawn, 2016, September 22).

News media in India takes pleasure in inciting the citizens against nuclear Pakistan in critical circumstances that could also turn into brutal confrontations or even warfare. However, Indian television bears much blame and liability than the print media for spoiling peace by encouraging 
war-oriented stories that are prone to inflame and incite the Indian public in crisis situations against its nuclear-armed neighbor as the Indian viewers are often exposed to misinformation, sensational scoops and journalistic malpractice propagated through television news content regarding Pakistan. Therefore, the views and attitudes of the public rely mainly upon how the events are propagated through the media. With media being an influential projector of the issues, the viewers tend to believe in the reality portrayed via media (see Malcheff, 2010).

Indian news television never rechecks the accuracy of obtained information of the stories against Pakistan (see, e.g., Kaur et al., 2018). In fact, this information has predominantly contributed in the ever-continuing undeclared war amongst India -Pakistan. This trend of media, being governed by business interests and sensational scoops, have developed into significant cohorts in government's propagandistic designs thereby cultivating revulsion and biasness in public's mindset especially against its perceived opponents including nuclear Pakistan. Most importantly, radicalization, ethnic violence, Pakistan obsession and political landscape have impeded the genuine functioning of Indian media. Furthering hostility a lot of lies, bluffs and half-truths were witnessed while the news reporting has fallen prey to stereotyping, wishful thinking and propaganda in India against Pakistan.

The $21^{\text {st }}$ century had experienced a considerable boost in the intensification of diverse news media in India against Pakistan. Indian news -media exceedingly benefited from elongated democratic rule, deeply embedded with political designs. Indian propagandistic tactics has always victimized Pakistan. The phenomenon of Indian new media demonstrates the worst possible outcome of biased and predisposed way of reporting in critical situation that could even take the form of war or threat of war. The attack on Indian parliament on 13 December 2001 is an example in this regard. News channels in India deliberately try to create Pakistan an external enemy through their news coverage (see, for example, Paul and Paul, 2005). For example, the 2001 Indian Parliament attack was portrayed as an attack at the Parliament of India in New Delhi on 13 December 2001 and the one-hour long gun battle was broadcast live on 


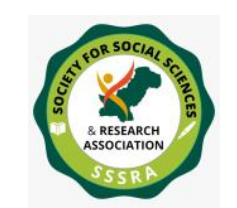

news channels. Appendix A exhibits select instances of manipulative Indian news coverage employing the malicious, outright lies that appeared in the Indian mainstream media in this regard.

Relations between India and Pakistan disintegrated seriously after the strike. India guaranteed, Pakistan is in charge of the assault, L K Advani (home serve) consider dependable the assault on two Kashmiri spotter bunches Lashkar-e-Taiba and Jaish-e-Mohammed and denounced (ISI) Pakistan's Inter-Services Intelligence of being Involved. He reports the incident as the most disturbing demonstration of fear-based oppression throughout the entire existence of too many years of Pakistan-supported psychological warfare in India, blaming the psychological oppressors and their tutors of endeavoring to crash the whole political initiative of India. Advani pronounced, We will exchange the fear-based oppressors and their patrons whoever they are, any place they are. An extreme discussion was in progress in Indian decision hovers over a gigantic military negative mark against dissenter preparing camps in Pakistan-held Kashmir, an enormous military hostility that carried India and Pakistan to the edge of war with fingers on the atomic trigger. General Pervez Musharraf denounced the assault on the Indian parliament yet cautioned against any steep activity by the Indian government against Pakistan warning the it would prompt intense repercussions. Pakistan denied any association in the assault and, in any event at first, inferred that India may have organized it for its own political purposes. India has officially requested that Pakistan closed down the workplaces of the Jaish-e-Mohammed and Lashkar-e-Taiba gatherings, capture their members and stop their progression. Advani said India would watch for a couple of days, suggesting that reprisal against Pakistan would be quick if its requests were not met. Musharraf had demanded India to provide verification before Pakistan makes any move against the Kashmiri gatherings. A significant number of the equipped Kashmiri associations have close associations with the Pakistani military, however none have guaranteed obligation regarding the assault Indian Prime Minister Atal Behari Vajpayee cautioned that India would dispensed discipline subsequent to researching the obnoxious wrongdoing, including that the discipline will be as large as the wrongdoing. He obtusely proclaimed to parliament, The 


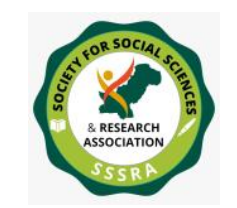

point of the discussion should be whether or not there should be war and under what circumstances. India would use diplomacy as a weapon, but other options are open. Indian parliament and media pushed its government for military activity and seek Washington's help for India's case being similar to the Sharon government's assaults on Palestinians. BJP MP Srichand Kripalani stated, The legislature ought to do what America has done in Afghanistan and what Israel is doing in Palestine. The legislature ought not avoid assaulting Pakistan. The underlying US reaction was for India to take proper activity in the wake of deciding obligation regarding the appalling demonstrations. Later US Secretary of State Colin Powell cautioned, that the circumstance could winding wild. In comparable vein, White House representative Ari Fleischer requested for India and Pakistan to step back. This isn't a purpose behind India and Pakistan to make a move against one another, he said. This is a period for India and Pakistan to make a move against the fear-based oppressors. Indian PM Vajpayee composed straightforwardly to Bush, cautioning that, Pakistan must comprehend that there is an utmost to the tolerance of the individuals of India. On 20 December, in the midst of calls from the United States, Russia, and the United Nations to practice limitation, On December 21, India suspended air, rail and transport interchanges and restricted over-flights with Pakistan. It put into movement a monstrous activation of its war apparatus, sent atomic rockets and moved numerous soldiers to the Pakistan fringe and effectively propelled its war exertion against Pakistan. India asserted the it had 'indisputable proof' of Pakistan's association. Afzal's admission was the main 'confirmation' of Pakistan's association that the administration had Afzal's admission. National Security Adviser to US President George W Bush Condoleezza Rice said that India would not move under US strain to hold any discussions with Pakistan. Indian Foreign Minister Yashwant Sinha in a meeting with the Hindustan Times on April 3 said India had a greatly improved case to go for a preemptive action against Pakistan than the United States had in Iraq, an argument echoed and endorsed by Defense Minister George Fernandes (People's Daily Online, 2003, Dec 20).

The Pakistani initiative cautioned India of grave results in the event that it set out on any misfortune and said there ought to be no misconception 
with respect to India about Pakistan's ability to safeguard itself. The United States additionally asked India not to draw parallels between the Iraq and Kashmir circumstances and to limit itself from utilizing the war against Iraq as an appearance for an assault on Pakistan. Things changed after India received the clear signal sent from the United States. Apparently to ward off pressure and avoid interference in the Kashmiri affairs by the world powers, Indian PM Atal Behari Vajpayee offered Pakistan talks surprisingly on April 18. We are willing to discuss all issues including Jammu and Kashmir, Vajpayee said, stressing that his country wanted friendly relations with its western neighbor. Pakistani Prime Minister Zafarullah Jamali did not hesitate to take Vajpayee's hand of friendship. He called Vajpayee personally on April 28 to invite him to visit Islamabad. The peace ball began rolling and the two neighbors' 17-month long impasse came to an end (People's Daily Online, 2003, Dec 20).

However, The Times of India reported on July 14,2013, that a member of Special Investigating Team (SIT) of Indian Central Bureau of Investigation had accused incumbent governments of orchestrating the terror attack on Indian Parliament 2001 and the 2008 Mumbai attacks 26/11 carnage (Times of India, 2013, July 14).

\section{Conclusion}

Majority of the times, it is the state that decides the agenda of response to the conflict situation, however there are times when media through its coverage pressurizes the state for a certain response. The portrayal from the media of Indian side has tended towards exasperating instead of settling issues. The Indian media shows lack of an unprejudiced account of the circumstance, continues raising the issue and sensationalizing and seen advancing their own motivation, as indicated by their own personal circumstance. The inclusion of the fear mongering occasions grandstand that undue favorable position of the right to speak freely has been taken, disregarding media morals. The ultimate target of Indian media seems to declare Pakistan as the host of the Ivy League of terrorism (Bajpai, 2003, Kapur, 2006). Albeit never unequivocally expressed, every discourse leads towards the possibility that expelling talks and taking steps to do battle 
with Pakistan is the main arrangement that India has in its protective layer (Riedel, 2013). What it ignored in the process is that it is keeping away from off its commitment of fit news throwing, which is typical from the fourth pillar of vote-based framework, as it is much of the time called (Keane, 1992). 


\section{Appendix A:}

\section{Select Instances of Manipulative News Coverage of Indian media}

Neeta Sharma and Arun Joshi, (2001, December 16). Case Cracked: Jaish behind Attack" The Hindustan Times: "In Delhi, the Special Cell detectives detained a Lecturer in Arabic, who teaches at Zakir Hussain College (Evening) ....after it was established that he had received a call made by militants on his mobile phone." (Roy, 2009)

"DU Lecturer was terror plan hub" (2001, December 17) The Times of India: "The attack on Parliament on December 13 was a joint operation of the Jaish-e-Mohammed (JeM) and Lashkar-e -Toiba (LeT) terrorist groups in which a Delhi University lecturer, Syed A.R.Gilani, was one of the key facilitators in Delhi, Police Commissioner Ajai Raj Sharma said on Sunday." (Roy, 2009)

Devesh K. Pandey. (2001, December 17), Professor Guided the 'Fidayeen' The Hindu: "During interrogation Geelani disclosed that he was in the know of the conspiracy since the day the 'fidayeen' attack was planned." (Roy, 2009)

Sutirtho Patranobis (2001, December 17) "Don lectured on terror in free time" The Hindustan Times: "Investigations have revealed that by evening he was at the college teaching Arabic literature. In his free time, behind closed doors, either at his house or at Shaukat Hussain's, another suspect to be arrested, he took and gave lessons on terrorism..." (Roy, 2009) 


\section{References}

Bajpai, K. S. (2003). Untangling India and Pakistan. Foreign Affairs, 82, 112.

Dawn (2016, September 22). Pak-India Media War. https://www.dawn.com/news/1285226.

Kapur, S. P. (2006). The India-Pakistan Conflict: An Enduring Rivalry. Canadian Journal of Political Science, 39(4), 966.

Kaur, K., Nair, S., Kwok, Y., Kajimoto, M., Chua, Y. T., Labiste, M., ... \& Kruger, A. (2018). Information disorder in asia and the pacific: Overview of misinformation ecosystem in australia, india, indonesia, japan, the philippines, singapore, south korea, taiwan, and vietnam. Carol and Jo, Hailey and Lin, Lihyun and Le, Trieu Thanh and Kruger, Anne, Information Disorder in Asia and the Pacific: Overview of Misinformation Ecosystem in Australia, India, Indonesia, Japan, the Philippines, Singapore, South Korea, Taiwan, and Vietnam (October 10, 2018).

Keane, J. (1992). Democracy and the media-without foundations. Political Studies, 40 (1), 116-129.

Khanum, M. (2020, Dec 10). Strain on India-Pakistan Relations through Indian Media. 2nd International Conference on Social Science and Humanities https://www.dpublication.com/wpcontent/uploads/2020/11/18-5018-1.pdf

Kumar, K. J. (2000). Mass Communication In India (Vol. 741). Jaico Publishing House.

Lyon, P. (2008). Conflict between India and Pakistan: An Encyclopedia. Abc-Clio. 
Malcheff, M. (2010). Public Perception or Media Manipulation: The Power of the Agenda-Setting Function of the Press Examined. M.A Liberty University Press.

Paul, T. V., \& Paul, T. V. (Eds.). (2005). The India-Pakistan conflict: an enduring rivalry. Cambridge University Press.

People's Daily Online. (2003, Dec 20) India, Pakistan inch tentatively toward normalization of relations.

http://en.people.cn/200312/20/print20031220_130852.html

Riedel, B. (2013). Avoiding Armageddon: America, India, and Pakistan to the brink and back. Brookings Institution Press.

Roy, A. (2009). Field notes on democracy: Listening to grasshoppers. Haymarket Books.

Thussu, D. K. (Ed.). (2006). Media on the move: Global Flow and ContraFlow. Routledge.

Times of India (2013, July 14). Govt behind Parliament attack, 26/11:

Ishrat probe

officer.http://timesofindia.indiatimes.com/articleshow/21062116.cms?utm $\_$source $=$contentofinterest\&utm_medium $=$text\&utm_campaign $=$cppst. 